\title{
Introduction: Time and Space in the Neoliberal University
}

\section{Maddie Breeze, Yvette Taylor, Cristina Costa}

'Neoliberal' is a ubiquitous and perhaps over-used concept in current debates about higher education (HE). Alongside other useful terms used to analyse contemporary conditions for academic labour in the 'performative' (Pereira 2016) and the 'entrepreneurial' (Taylor 2014) university, we use it broadly in the collection title to refer to the ubiquitous extension of the principles of 'free market' capitalism particularly the logics of profit, individualism and competition. It is well established that the university is subject to and implicated in the reproduction of market logics, often identified in the tuition fees regime of England and Wales and the attendant lifting of caps on student numbers, but the local specificities glossed in such universalising claims remain in need of investigation and analysis. Accordingly, this collection attends to how time and space are configured, and intertwined, in higher education.

We are writing at a particular moment in time, in the accelerated (Vostal 2016) fast (Gill 2010) academy, in which evidence of the 'chronic stress, anxiety, and exhaustion' (Gill \& Donaghue 2016: 91) arising from the intensification and extensification of work in the 'greedy institution' (Hey 2004) is abundant. Here academics are 'time squeezed' and doing as much as possible as quickly as possible (Southerton, 2003); 'working harder and sleeping less' (Acker \& Armenti 2004: 3), and becoming 'too tired to think' (Pereira 2018).

At the same time, future-orientated temporalities are materialized in UK HE in multiple institutes of 'education futures', which are contested for example in the student occupation and inauguration of the 'Real Edinburgh Futures Institute' 
galvanized by University and College Union industrial action in March 2018 (Wallis 2018). We are writing at a time too when academic subjectivities are interpolated as future-orientated, articulated in the early-mid-established career course as academics are required to endlessly set their goals, and collate 'achievements', 'plans' and 'visions' in annual review processes and institutionally mandated career planning (Breeze \& Taylor 2018a), and chase research funds to guarantee research time, as if externally unfunded research lacked merit or value (Münch 2013). The requirement that academics bid for research funding requires a future orientation too, planning proposed projects and chasing elusive grants which bestow credibility as well as resources, increasingly necessary to guarantee research time, as if externally unfunded research lacked merit or value. Funding bodies structure access to grants temporally, in schemes for 'new investigators', 'future leaders', and 'young scientists' (ibid). Here - now - academic entrance, arrival, and success can be felt as permanently deferred (Taylor 2014) to an imagined future, if I get a more permanent contract, next semester, after this round of marking, when this bid is submitted just as everyday 'work goals' become an 'ever-receding horizon that cannot be reached' (Pereira 2016: 106).

Attending to contemporary moments in higher education brings the temptation of looking back nostalgically to idyllic times in which the university and those who worked within it were unbothered by market forces or the world - tellingly - below the ivory tower. Such imagined glory days both never really existed and are dependent on sweeping exclusions of women, working class, and BAME people. As the University of Glasgow recently 'discovered' (BBC 2018) how it 'benefitted from racial slavery and the profits it generated', and published proposed reparations (Mullen \& Newman 2018: 7) it is important to interrupt comfortingly linear narratives 
of both 'decline' and 'progress'. Such narratives are only possible to sustain if we ignore, for instance, universities' foundational and continuing roles in liberal settlercolonial state-building and as agents of border control in racist capitalism (Dear 2018). Thinking through time and space in the neoliberal university means getting tangled up in contested and political distinctions between then and now, and avoiding over-simplified linear diagnoses of the problem as occurring exclusively then, or only now.

Articulating the then and now, and the here and there, of higher education is bound up too with the reproduction of epistemic status, as Pereira (2014: 627) has shown how 'the importance of being "modern" and foreign' in epistemic heirarchies is mapped on to nations. Higher education is fractured by global hierarchies, national and 'world' rankings ${ }^{\mathrm{i}}$, the dominance of Anglophone publishing, and the tokenizing of scholars and scholarship from the global south. The language used to describe academic work articulates on-going investments in the spatial configurations of colonial expansion and extraction - pioneering research, pump priming the research pipeline (McLean 2018, de Leeuw 2017).

As activist movements and scholarship that aim to decolonize the university gain traction it is crucial to ask how sincere institutional efforts to 'decolonise' are (Arday \& Mirza 2018, Bhambra et al 2018). This question becomes even more important when UK research funders and university schemes incentivize 'partnerships' in the global south in the name of 'international development' and 'global challenges'. In 'Decolonisation is not a Metaphor', Tuck and Yang (2012: 1) identify how the metaphorical use of decolonization 'makes possible a set of evasions... that problematically attempt to reconcile settler guilt and complicity, and rescue settler 
futurity'. These authors clearly state that 'decolonization brings about the repatriation of Indigenous land and life; it is not a metaphor for other things we want to do to improve our societies and schools' (ibid).

As attention is drawn and re-drawn to the whiteness of curricula, cannons, disciplines, and universities (Ali et al. 2010, Mirza 2015) 'diversity' is increasingly mainstreamed in higher education policy and governance. Diversity is then figured as a desirable, promotional characteristic of the university ${ }^{\mathrm{ii}}$ (Mirza 2006; Taylor 2013). Yet such institutional commitments can be understood as 'non-performative' and not only do not bring about the diversity they name, but function to block attempts at its realisation (Ahmed 2012a 2012b).

The materiality of exclusionary structures in higher education is clear in 'Brick Walls' a chapter in Living a Feminist Life that 'think[s] about materiality through institutional brick walls' (Ahmed 2017: 142). In Ahmed's analysis, brick walls are what diversity workers come up against, as racism and sexism become walls in the university, formed and sedimented through exclusion; 'Walls are how some bodies are not encountered in the first place' (Ahmed 2017: 145, and see Puwar 2004). Attending to the spaces of higher education - from global HE inequalities across and between nations, 'satellite campuses', 'Global Challenge' funding and collaborations with 'developing nations', to doors which bar access without a swipe card, open plan offices, teaching rooms without enough chairs, the names of buildings and the marble busts and oil paintings inside them - is a key concern of the chapters that follow.

As editors we are writing from the UK, and contributors are writing in and about UK and Australian HE, attending to their locatedness in relation to higher education in global context. This particular collection of chapters then repeats entrenched problems 
with the dominance of English-language publishing and the globalizing of some HE systems as the university, as we repeat, rather than resolve, such inequalities in time and space. We can think of how academics - especially but not only when studying education - are implicated by their own practice and participation in the phenomena they seek to understand. We can think of the importance of understanding the UK HE system as it positions itself as exemplary and world leading, as setting the standards to be followed, as producing exportable models of Research and Teaching Excellence, and student satisfaction.

The enduring materiality of institutions is felt too, by those academics on casualised, temporary, and insecure contracts which do not necessarily come with access to the resources required to do the job of teaching, research, and administration, including being paid for work done (Wänggren 2018). When UK based University and College Union (UCU) members, including academics and professional services staff, took part in the largest dispute in the history of the union, 14 days of industrial action in February and March 2018, it was to protect pensions. As discussed on picket-lines during the strike action, pensions are a form of deferred pay, bound up with investments in futurity encouraged in academic over-work. Later that year UCU members were balloted on industrial action over pay, including pay inequalities and casualization, only 10 universities met the 50\% turnout threshold (UCU 2018).

Academic labour is restructured to accommodate precarity. This is visible in the type of contracts that are offered through the UK HE system (casualised short-term, part time, and zero-hour). Such structural changes ensues a set of inequalities that sees academics' role as knowledge workers declining in social and economic status. These processes are exacerbated as universities are beholden to national research and 
teaching benchmarks that assert their position in the academic marketplace, nationally and internationally.

In the case of the UK, Universities are bound by regular Research Excellence Framework (REF) audits of research capacity. Such exercises avowedly gauge - and work to discursively produce - universities' symbolic power, prestige and recognition. The consequences for individual academics are clear in the redefinitions of REF guidelines, for example, in the introduction of partial, interim 'nonportability' rules for the 2021 audit. Here the association of research outputs with an institution as well as the researcher(s) that produce them means that importance is placed on the welfare of the institution rather than their workers. Such regulatory changes emphasise the university as a dominant power and limit academics' mobility in navigating increasingly fractured career paths. This cannot be regarded as 'good news for those who have invested in long-term research strategies, but bad news for those who have not' as asserted by Murphy $(2017: 37)$ as doing so would be to conceal the unequal working conditions and opportunities in academia. Rather, the discontinuity of total portability of outputs in future REF exercises implies that academics will face increased difficulties in career progression, even when playing the game and mobilizing their publications as employment currency, since it seems likely that these will be formally attached to universities. The neoliberal university adjusts itself to serve its goals, entrenching hierarchies among staff, students, and institutions.

Just as academics travel, and are interpolated as mobile subjects, we write, and work, from institutional locations that place us within the stratified national and international rankings of universities in competition with each other. We see a 
colleague introduced with her 'primary' institutional affiliation, she responds by naming the two other universities she is currently working for on casualised contracts. Writing some of this introduction in office space at the University of Strathclyde I hear the drilling and driving noise of construction, another 'statement' building. As the new sports centre is built, anticipating student recruitment and satisfaction scores, our pathways through and across campus are shaped by a shifting maze of temporary fences, blocking pavements, ramps, and stairways. Writing this introduction we read news about Hungary's Prime Minister and leader of the far-right Fidesz-KDNP alliance government Viktor Orban moving to ban gender studies in the country's universities, and reports of police entering universities in Brazil to remove anti-fascist materials after Jair Bolsonaro's far-right 'Social Liberty Party' electoral win (Phillips 2018).

All the while we remain invested - if ambivalently, reluctantly, critically - in higher education as a site of hope and possibility, for transformative queer, feminist, antiracist ways of knowing and being (Mirza 2008, Gunn 2018). In these times and places we're left with the question of what to do with these cruelly optimistic desires and self-defeating attachments (Berlant 2011); how to inhabit educational hopes and disappointments. The chapters that follow, in part, are framed by and unpick these questions.

Alongside a Special Issue on 'Futures and Fractures in Feminist and Queer Higher Education' (Breeze and Taylor 2018b) this edited collection is one product of the Educational Futures and Fractures conference organized by one co-editor, Yvette Taylor, at the University of Strathclyde (Glasgow, Scotland) in February 2017. The conference bought together speakers from across and beyond the UK, including a 
keynote from Prof Rowena Arshad OBE and invited talks from Dr Amy Pressland and Dr Rachel Thwaites. With the conference we set out to share new interdisciplinary analyses of borders, boundaries, blockages and im/mobilities in higher education, and how these might be identified, inhabited, resisted, and reworked. We are working in a context where the future of higher education is uncertain and the sector remains stratified by and complicit in entrenched inequalities of access and outcomes among students and staff, with boundaries of who does and does not belong continually drawn, enacted, contested, and redrawn in the spatial and temporal locations of higher education. The collection is concerned partly therefore with how alternative academic futures can be claimed despite the neoliberal university.

\section{CHAPTER SUMMARY}

In Chapter 2 Closed doors: Academic collegiality, isolation, competition and resistance in the contemporary Australian university Bryony Lipton explores collegiality in neoliberal university spaces. Lypton analyses in-depth qualitative interviews with women academics alongside critical autoethnographic reflections, and argues that collegiality is best conceptualised as a set of gendered practices and performances rather than a quality or virtue. The chapter traces how academic women articulate the complexity and contradiction of collegiality discourse, and as a consequence, are rendered invisible in different academic spaces. Lypton also demonstrates how academic women create alternative spaces for feminist collectivity in the shifting spaces of Australian higher education.

In Chapter 3 Feminist pedagogy: Fractures of recognition in higher education Genine Hook considers generative feminist pedagogies for creating educative spaces and queering privilege and normative social structures in the process. In doing so Hook 
analyses how everyday institutional and educational norms can be contested and reworked. Hook explores how students grapple with feminist activist pedagogy in ways that can include attempts to re-assert normative, hierarchical dominance. Alongside this, early career feminist academics encounter conditions of recognition based around student survey data, promotion criteria, casualisation and market-driven student expectation and demands. Hook follows Ahmed's (2017), Living a Feminist Life, to articulate how the personal as theoretical is embedded in becoming-academic.

In Chapter 4 (Dis)assembling the neoliberal academic subject: when PhD students construct feminist spaces Elizabeth Ablett, Heather Griffiths and Kate Mahoney reflect on the paradox of becoming entangled in neoliberal practices based on their experiences organising a critical workshop for doctoral students and working to create alternative academic spaces. Ablett et al approach the workshop as a conceptual framework of analysis, and interrogate their own feminist practices, including how these are embedded in the intensification of doctoral life. The workshop produced tensions between solidarity and critique, and the chapter explores how creative activities such as zine-making can interrupt academic productivity norms. The authors tease out the challenges of continuing this work beyond the workshop and into everyday doctoral spaces.

In Chapter 5, Making feminist(s) work through out the career course Maddie Breeze and Yvette Taylor explore how inhabiting categorical academic career stages uncritically can serve to reproduce neoliberal academic structures that feminists may seek to resist and rework. Breeze and Taylor use auto-ethnographic methods to read career stages and feminist collaboration through each other, analysing the authors' mentoring relationship and cross-career collaborations. The authors consider how 
feminist collaboration can claim and disrupt the neoliberal temporal logics of competitively achieving individuals on upwardly mobile career paths. As such they argue for more pluralised and fragmented understandings of 'career stages', which as fixed categories work to position academics as either precarious or privileged, and for a messier imaginary of academic work and careers.

\section{In Chapter 6 Black Scottish writing and the fiction of diversity Churnjeet Mahn} operationalises two different lenses to consider teaching postcolonial literature in the Scottish university classroom: the use of 'postcolonial' in Scottish literary studies to partially figure the relationship between Scotland and England, and discussions of race in Scotland through recent iterations of an inclusive Scottish civic nationalism. Mahn argues that as politicised histories of racism are displaced to the broader British context, alongside Scotland's own framing of colonial and colonised history, race is de-emphasised as a marker of difference in Scottish literary criticism. However, Scottish writing by ethnic minorities produces a more ambivalent position on race and nationalism, and a more ambivalent appreciation of the relationship between race and nationalism. This contradiction illustrates the ideological tensions that characterise teaching race in Scotland.

In Chapter 7 The imperial/neoliberal university: what does it mean to be included? Lou Dear explores how movements like Rhodes Must Fall identified institutional racism at the heart of UK universities, just as a range of activists argue that addressing the underrepresentation of marginalised staff and students is only one part of a complex path towards decolonisation. In this context, as imperial/neoliberal universities mobilise internationalisation and widening participation agendas, the politics of diversity and inclusion are critiqued (Ahmed 2012). Dear illuminates the 
experience of participating in British higher education institutions by reading David Dabydeen's The Intended (1991) and Diran Adebayo's Some Kind of Black (1997). The chapter therefore illustrates the race, class and gendered costs of inclusion within the imperial/neoliberal university. Reading the texts reveals how universities covet certain bodies and simultaneously destroy alternative ways of thinking and being, interpersonal relationships, and community and kinship bonds.

In Chapter 8 In defence of safe spaces: subaltern counterpublics and vulnerable politics in the neoliberal university Chris Waugh pursues an analysis of 'safe spaces' policies in UK Universities, arguing that such policies encourage reflexive behaviour, and acknowledgements of societal privilege and dynamics of oppression. Drawing on Butler and Fraser, Waugh contends that safe spaces can be conceptualised as counterpublics; offering imperfect but vital spaces of opposition to neoliberal discourses of resilience and allowing recuperation and resistance formation. Waugh contends that criticism of safe spaces is also a criticism of the rejection of imperatives for neoliberal resilience.

In Chapter 9 Public sociology and social movements: incorporation or a war of position? Eurig Scandrett and Elaine Ballantyne consider how activist academics work to challenge neoliberalism in higher education via collaborative engagement with various social movements. The authors draw on their experiences working with movements against violence against women; for environmental justice; and mad studies. They mobilise Gelpi's understanding of lifelong education to analyse the dialectical relations of knowledge exchange that inhere in such collaborations, and which works to expose and transform social contradictions. However, such projects also encounter the risk of hegemonic incorporation into the neoliberal university. The 
authors argue that the Gramscian concept 'war of position' helps to identify such risks, and that collaborative pedagogy can raise a defence against neoliberal attacks on social movements, as well as providing opportunities to challenge neoliberal hegemony in higher education.

In Chapter 10 Discourses of dissonance: enabling sites of praxis and practice amongst Arts and Design doctoral study Jacqueline Taylor explores how PhD study occupies a fractional, anomalous space in the university. Taylor argues that the Arts \& Design $\mathrm{PhD}$, party by virtue of a complex relationship with practice, disrupts the normative frameworks of the academe and the broader landscape of doctoral research. Taylor explores transformational, performative and embodied spaces of learning, teaching and becoming as part of a spatiotemporality that brings to the fore spaces of praxis and practice. The chapter demonstrates how, while dissonance is normally conceived as a negative lexicon, the dissonance of the Arts \& Design PhD can be reconceived as a generative para-dox in eliciting 'doctoralness'.

In Chapter 11 An embodied approach in a cognitive discipline Jennifer Leigh foregrounds how academia can be an uncomfortable place to work, as a cerebral, critical, competitive and judgmental environment. Leigh discusses a study that used creative research methods with academics who self-identified as having an embodied practice, and defines embodiment to mean both a state of being and a process of learning about the self. Arguing that embodied practices are ways of bringing conscious self-awareness to and about the body, Leigh demonstrates how participants reflected on the meanings they attributed to their own embodied practices, including tensions with their embodied identity, and 'wellbeing' imperatives in the neoliberal university. 
In Chapter 12 Aesthetic Education and the Phenomenology of Learning Jonathan

Owen Clark and Louise H. Jackson attend to the limitations of temporal

consciousness in contemporary UK higher education, as manifest in an accelerated neoliberal present. The authors undertake a phenomenological and pragmatist reading of meaning-formation, learning and temporal consciousness, adopting critical approaches from aesthetic theory. This enables the positing of an 'aesthetic education' that exposes and makes visible neoliberal narratives that are temporally and pedagogically suppressive, thereby linking the phenomenological with the political. The chapter builds to an examination of polylogical pedagogies, especially in the arts, that are fundamental to resisting the foreclosure of potenail in learners and educators alike.

The collection draws to a close with Chapter 13 Response-ability: Re-e-valuing shameful measuring processes within the Australian academy in which Melissa Joy Wolfe and Eve Mayes consider how evaluative practices dominate contemporary Australian higher education. Such measures are analyses as reductive and as limiting knowledge-making capacity. The chapter reads 'evaluation' through two of the authors' own personally stultifying and shameful encounters within measurement in the Australian academy. This critique does not simply oppose evaluative methods but crafts a conceptualisation of evaluation as mattering otherwise. The authors therefore promote an ethics of affect in relation to academic performance evaluation, by considering how consequences of evaluation are always co-constituted. Evaluation processes are thus re-conceptualised response-ably, in order to build capacity for a diversity of knowledges and to matter otherwise. 


\section{References}

Acker, S. \& Armenti, C. (2004). Sleepless in academia. Gender and Education, 16(1), 3-24.

Ahmed, S. (2012a). Embodying diversity: Problems and paradoxes for Black Feminists. In Taylor, Y. (Ed.), Educational Diversity: the Subject of Difference and Different Subjects. Basingstoke: Palgrave Macmillan.

Ahmed, S. (2012b). On being included: Racism and diversity in institutional life. Durham, NC: Duke University Press.

Ahmed, S. (2017) Living a feminist life. Durham, Duke University Press.

Ali, S. Mirza, H., Phoenix, A. \& Ringrose, J. (2010). Intersectionality, Black British feminism and resistance in education: a roundtable discussion. Gender and Education, 22(6), 647-661.

Arday, J. \& Mirza, H. S. (Eds.). (2018). Dismantling Race in Higher Education Racism, Whiteness and Decolonising the Academy. Palgrave Macmillan.

BBC (2018) Glasgow University 'benefited from slave trade profits'. Retrieved from: https://www.bbc.co.uk/news/uk-scotland-glasgow-west-45539706

Berlant, L. (2011). Cruel optimism. Durham: Duke University Press.

Bhambra, G. K., Gebrial, D. \& Nisancioglu, K. (Eds.). (2018). Decolonising the University. London: Pluto Press

Breeze, M and Taylor, Y (2018a) Feminist collaborations in higher education: stretched across career stages. Gender and Education [online advance publication]

Breeze, M and Taylor, Y (2018b) Introduction, Futures and fractures in feminist and queer higher education. Journal of Applied Social Theory 1(2)

de Leeuw, S (2017) Writing as righting: Truth and reconciliation, poetics, and new geo-graphing in colonial Canada. The Canadian Geographer 61(3): 306-318

Dear, L. (2018). British University Border Control: Institutionalization and Resistance to Racialized Capitalism/Neoliberalism. The International Education Journal: Comparative Perspectives, 17(1), 7-23.

Gill, R \& Donaghue, N. (2016). Resilience, apps and reluctant individualism: Technologies of self in the neoliberal academy. Women's Studies International Forum, 54, 91-99. 
Gill, R. (2010). Breaking the silence: The hidden injuries of neo-liberal academia. In R. Flood \& R. Gill (Eds.), Secrecy and Silence in the Research Process: Feminist Reflections. London: Routledge.

Gunn, V. (2018). Queer desire's orientations and learning in higher education fine art. Journal of Applied Social Theory. 1(2): 35-57.

Hey, V. (2004). Perverse pleasures - Identity work and the paradoxes of greedy institutions. Journal of International Women's Studies, 5(3), 33-43.

Mirza, H. S. (2006). Transcendence over Diversity: Black Women in the Academy. Policy Futures in Education, 4(2), 101-113.

Mirza, H. S. (2008) Race, gender and educational desire: why black women succeed and fail. London, Routledge.

Mirza, H. S. (2015). Decolonizing Higher Education: Black Feminism and the Intersectionality of Race and Gender. Journal of Feminist Scholarship, 7/8, 1-12.

McLean, H (2018) It's time universities walk their decolonial talk https://www.timeshighereducation.com/blog/its-time-universities-walk-theirdecolonial-talk

Münch, R. (2014). Academic Capitalism : Universities in the Global Struggle for Excellence. Routledge. https://doi.org/10.4324/9780203768761

Mullen, S. and Newman, S. (2018). Slavery, Abolition and the University of Glasgow: report and recommendations of the University of Glasgow History of Slavery Steering Committee. Retrieved from: https://www.gla.ac.uk/media/media_607547_en.pdf

Murphy, T. (2017). Revising the Research Excellence Framework: ensuring quality in REF2021, or new challenges ahead? Perspectives: Policy and Practice in Higher Education, 21(1), 34-39. https://doi.org/10.1080/13603108.2016.1246386

Pereira, M. (2014). “The Importance of Being 'Modern' and Foreign: Feminism and the Epistemic Status of Nations", Signs: Journal of Women in Culture and Society, 39 (3), 627-657.

Pereira, M. (2016). Struggling within and beyond the Performative University: Articulating activism and work in an "academia without walls". Women's Studies International Forum, 54, 100-110.

Pereira, M. (2018). Too tired to think: On (not) producing knowledge in the hyperproductive university. Talk at the University of York, February 2018. Retrieved from https://www.york.ac.uk/news-and-events/events/public-lectures/spring-18/too-tired/ 
Phillips, D (2018) Snitch on a teacher: Bolsonaro win sparks push against 'indoctrination'. The Guardian. Retrieved from:

https://www.theguardian.com/world/2018/oct/30/bolsonaro-win-students-urgedreport-teachers-who-complain-whatsapp

Puwar, N. (2004). Space invaders: Race, gender and bodies out of place. Oxford: Berg.

Southerton, D. (2003). 'Squeezing Time': Allocating Practices, Coordinating Networks and Scheduling Society. Time and Society, 12(1), 5-25.

Sullivan, N. \& Simon, J. (2014). Academic Work Cultures: Somatic Crisis in the Enterprise University. Somatechnics 4(2), 205-218.

Taylor, Y. (2013). Queer encounters of sexuality and class: Navigating emotional landscapes of academia. Emotion, Space and Society, 8, 51-58.

Taylor, Y. (Ed.) (2014). The entrepreneurial university: Engaging publics, intersecting impacts. Basingstoke: Palgrave Macmillan.

Tuck, E and Yang, K. W. (2012) Decolonization is not a metaphor. Decolonization: Indigeneity, Education \& Society. 1(1):1-40

UCU University and College Union. (2018). HE pay and equality ballot results. Retrieved from: https://www.ucu.org.uk/he_ballot_oct18

Vostal, F (2016) Accelerating Academia: The Changing Structure of Academic Time Basingstoke: Palgrave

Wallis, H (2018) BREAKING: Student occupation to continue. The Student Newspaper. http://www.studentnewspaper.org/breaking-student-occupation-tocontinue/

Wånggren, L. (2018) Feminist trade unionism and post-work imaginaries. Journal of Applied Social Theory, 1(2): 102-124.

\footnotetext{
i As I (Maddie) work on this introduction I look for an article on the Times Higher Education website. A pop-up invitation appears; do I want to compare eight universities and enter my details for a chance to win an iPad? I dutifully click on the links, following the instructions to choose between a series of paired university logos, which is the best?

ii Again, this introduction was written while both a 'REF audit' and a 'diversity audit' were underway at one of our institutions.
} 